\title{
SNOWDRIFT-ICE SLABS AND HISTORIC ANTARCTIC CLIMATIC WARMING*
}

\author{
By Robert L. Nichols \\ (Department of Geology, Tufts University, Medford, Massachusetts, U.S.A.)
}

THE term "snowdrift-ice" was first used by Wright and Priestley (1922, p. I 5 I-52) who defined it as "masses of ice or névé which are formed by the accumulation of drifted snow in the lee of projections [knobs, slopes, cliffs], or in depressions of the ground". They may be temporary, semi-permanent or permanent (Nichols, I 96o, p. I444-45; i 963 ; Hollin and Cameron, I96I, p. 835) depending upon precipitation, air and ground temperatures, insolation, humidity, cleanness of snow, geography, size and other factors.

Several more or less permanent patches of ice, most of which are not continuous with the Wilson Piedmont Glacier, are found near Gneiss Point and Marble Point (lat. $77^{\circ} 24^{\prime}$ S., long. $163^{\circ} 40^{\prime}$ E.), McMurdo Sound, south Victoria Land, Antarctica, which merit analysis (Nichols, I96I, p. 5I-53). Their proximity to the glacier at first suggests that they are detached stagnant remnants of the glacier. They are, however, snowdrift-ice slabs.

The prevailing winter wind is from the south, as proved by the following evidence: ( $\mathrm{I}$ ) ventifacts are cut and polished only on their south sides; (2) the sand shadows which form in the lee of obstacles occur on the north sides; (3) most of the grains and flakes which have been blown from blocks of marble and other rapidly weathering rocks are on the north sides of the blocks; (4) the largest snowdrifts are on the north sides of obstacles; and (5) the lee bedding in the snow barchans on the sea ice invariably slopes northwards.

All the ice slabs which were studied are on north-facing slopes. This is what would be expected if they were snowdrift-ice slabs, for although insolation is greater on north-facing slopes, snow would be deposited in greatest amount there because of the prevailing winds from the south (Fig. I). The writer visited several of these ice slabs during the spring before an

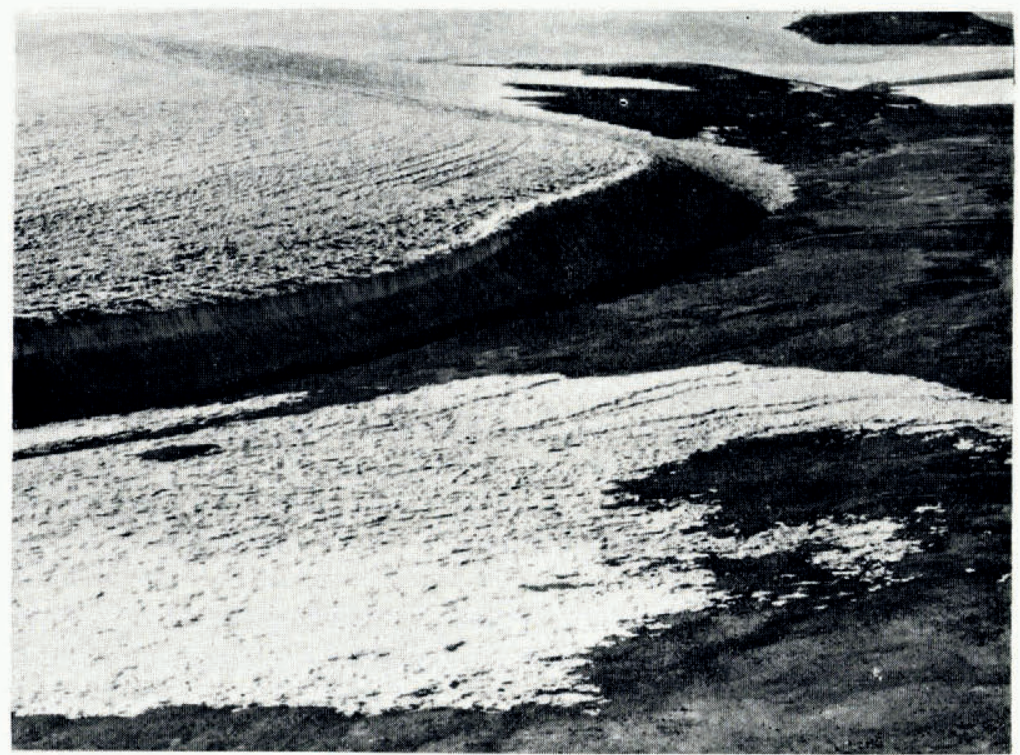

Fig. I. A snowdrift-ice slab on a north-facing slope adjacent to Wilson Piedmont Glacier and approximately $2 \mathrm{~km}$. west of Marble Point. (U.S. Navy photograph)

* Work supported by the Arctic Institute of North America and the National Science Foundation. 


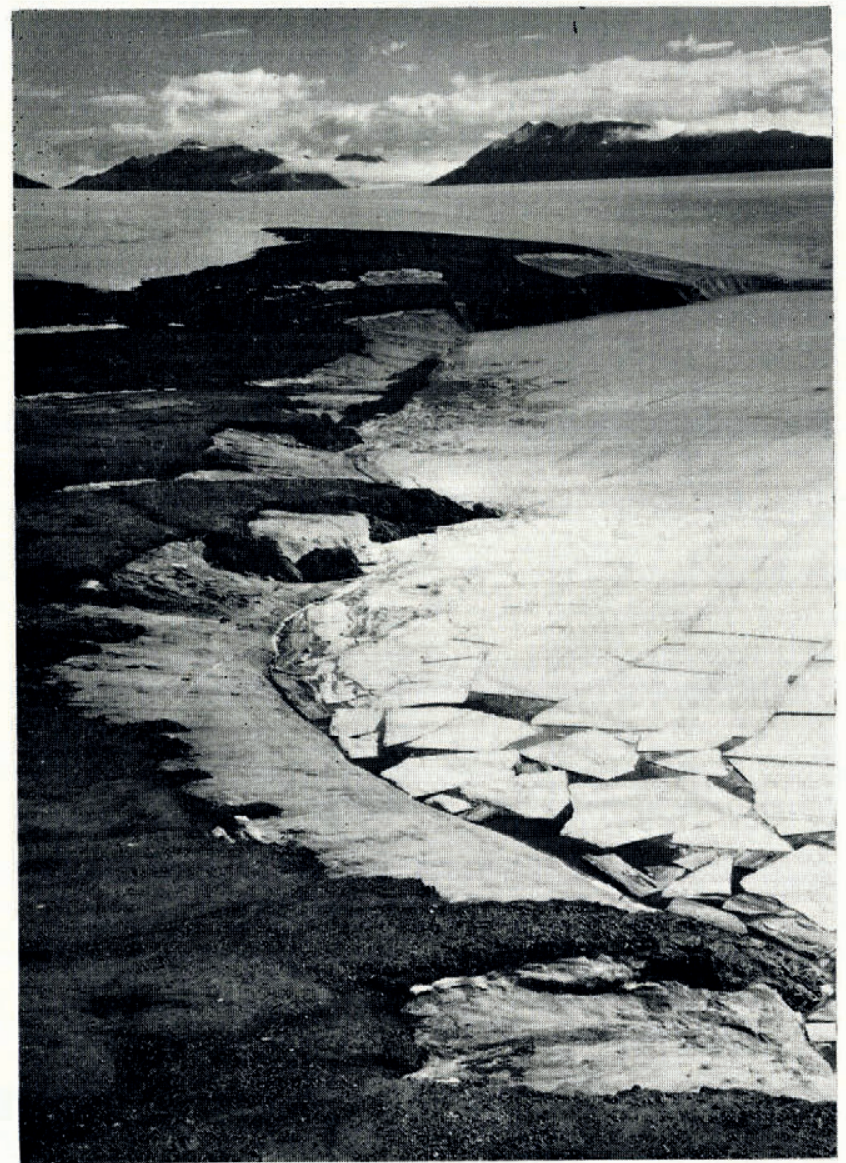

Fig. 2. Aerial photograph showing several north-facing snowdrift-ice slabs between Wright Glacier and Gneiss Point. Wilson Piedmont Glacier and Wright Glacier are in the distance. (U.S. Navy photograph)

appreciable amount of snow had ablated, and observed that the snow was deeper on northfacing slopes than elsewhere. Dirt layers in the ice slabs parallel their sloping surfaces. This also suggests that they are snowdrift-ice slabs rather than remnants of the glacier.

The snowdrift-ice slabs between Wright Glacier and Gneiss Point (Fig. 2) extend for approximately $2 \mathrm{~km}$. along the coast. They slope northward and extend from an upland surface down to sea-level. They are below the marine limit; therefore, they formed after the highest stand of the sea (Fig. 3). As the sea dropped in relation to the land, the snowdrift-ice slabs increased in size, growing outward and downward. They are undoubtedly less than $20 \mathrm{~m}$. thick. The absence of crevasses and the fact that their surfaces slope at only $\mathrm{I} 5^{\circ}$ prove that they do not move. Talus, fluviatile and beach deposits veneer them in places.

The most interesting snowdrift-ice slab extends from the upper part of the "Scheuren valley" almost down to sea-level (Fig. 4). The ice slab does not completely fill the valley, as the upland into which the valley has been incised is everywhere from 3 to $7 \mathrm{~m}$. above the surface of the ice slab. The slab (Fig. 5) is approximately $900 \mathrm{~m}$. long, I $00 \mathrm{~m}$. wide and, in places, $7 \mathrm{~m}$. thick. The "Scheuren River" during the summer months is sizable. In places, it runs in a tunnel beneath the ice slab; elsewhere, it runs in a canyon which it cut in the ice slab (Fig. 6). The upper part of the ice slab is above the marine limit, the lower part below it. Two factors 


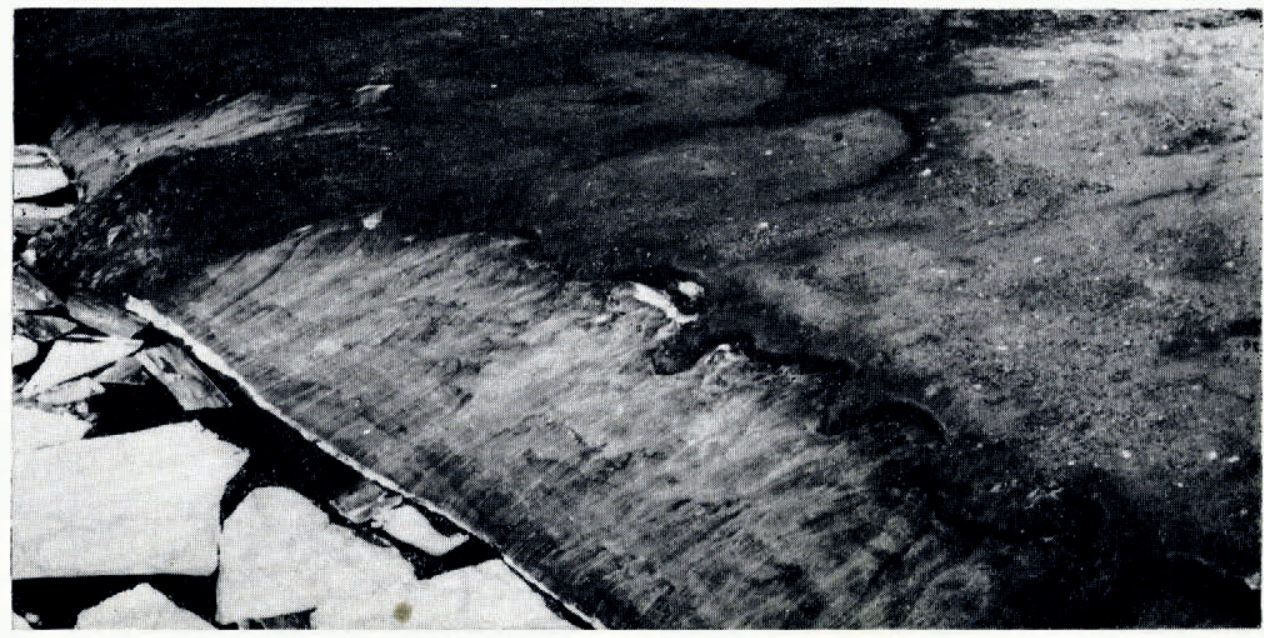

Fig. 3. A large and a small snowdrift-ice slab between Wright Glacier and Gneiss Point. The scalloped inner margin of the large slab may be due to nivation. Only a small patch of the previous winter's snow remains. The marine limit is a short distance above the inner margins of the slabs. (U.S. Navy photograph)

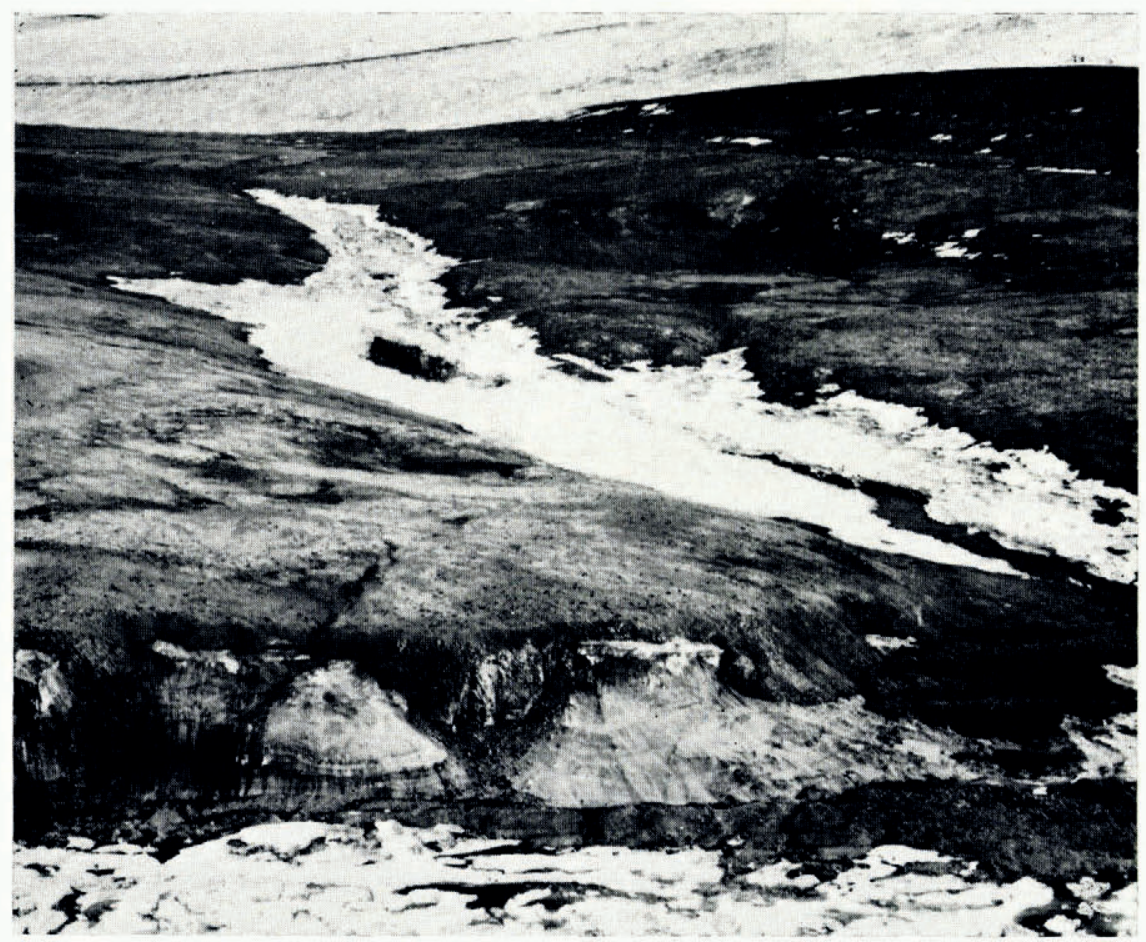

Fig. 4. Aerial photograph of the snowdrift-ice slab in the "Scheuren vallev". The river runs in places in a tunnel beneath the ice slab, in other places in a canyon cut in it. (U.S. Navy photograph) 


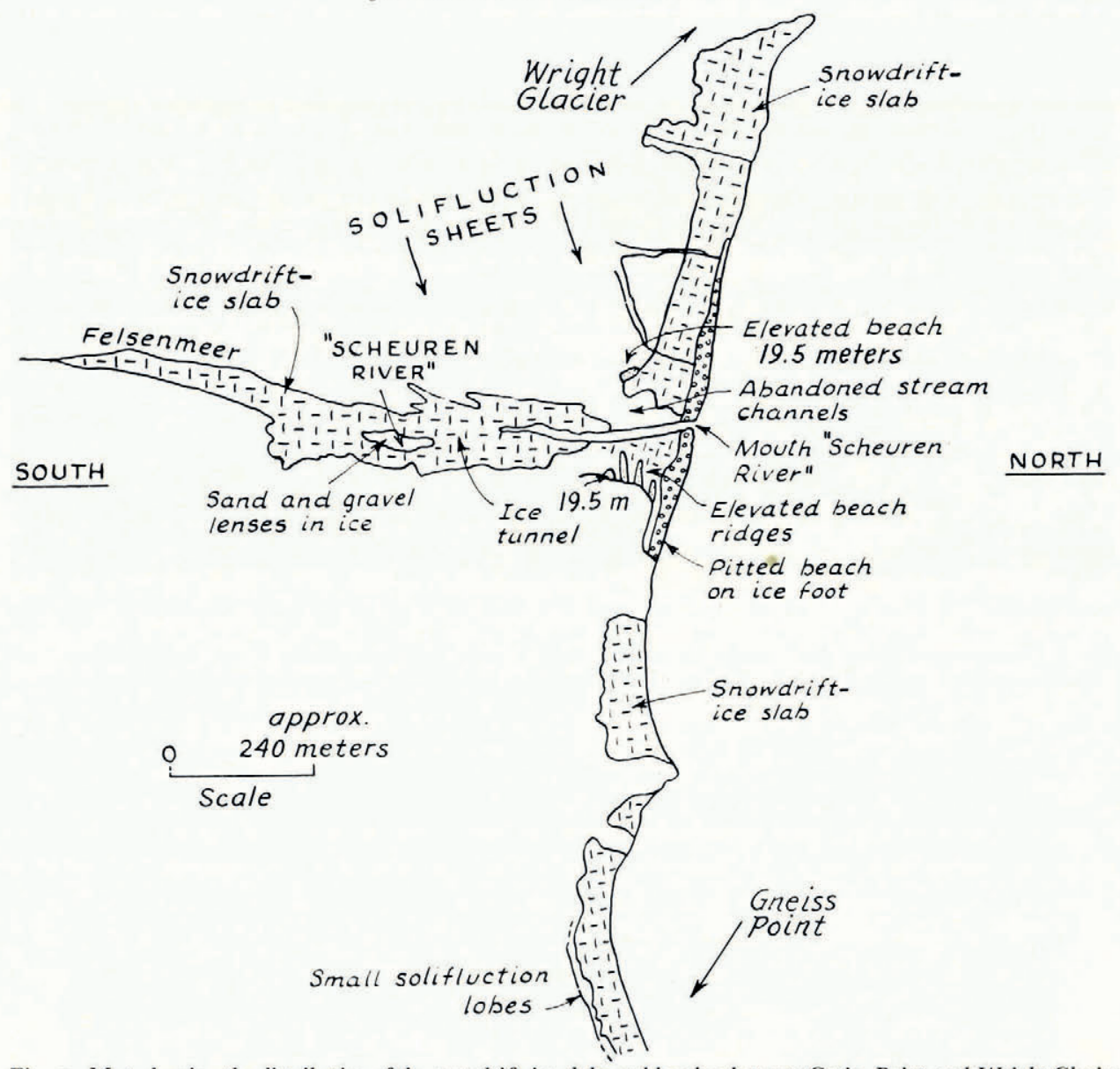

Fig. 5. Map showing the distribution of the snowdrift-ice slabs and beaches between Gneiss Point and Wright Glacier

favor its existence: it is on terrain which slopes northward, and it is in a valley 7 to $14 \mathrm{~m}$. deep which traps wind-drifted snow. The largest and deepest snowdrifts encountered in the Marble Point area were seen here.

The ice slab is not one solid unit of ice. It has many undeformed interbedded layers of fluviatile, cross-bedded sand and gravel less than $0.5 \mathrm{~m}$. thick (Fig. 7). They were deposited by the "Scheuren River" during the summer on snow which had accumulated during the winter. These layers show that the ice slab took many years to form and is composed in small part of river ice.

Temperature readings in pits dug in the Wilson Piedmont Glacier show that on the average, at an elevation of about $300 \mathrm{~m}$. above sea-level and at a depth below the surface of $7 \mathrm{~m}$., the glacier has a temperature of approximately $-22^{\circ} \mathrm{C}$. Subglacial and deep englacial streams therefore cannot exist at present, nor does it seem likely that they existed when the glacier covered the area under discussion. The interbedded sand and gravel in the ice slab proves, therefore, that the slab is not a detached stagnant mass of glacial ice, as the layers of sand and gravel could not have been deposited in glacial ice by streams; and had the sand and gravel been originally deposited on the surface of the glacier and later buried, deformation of the layers would be expected. The layers have neither the attitude nor the characteristics of shear-plane deposits. 


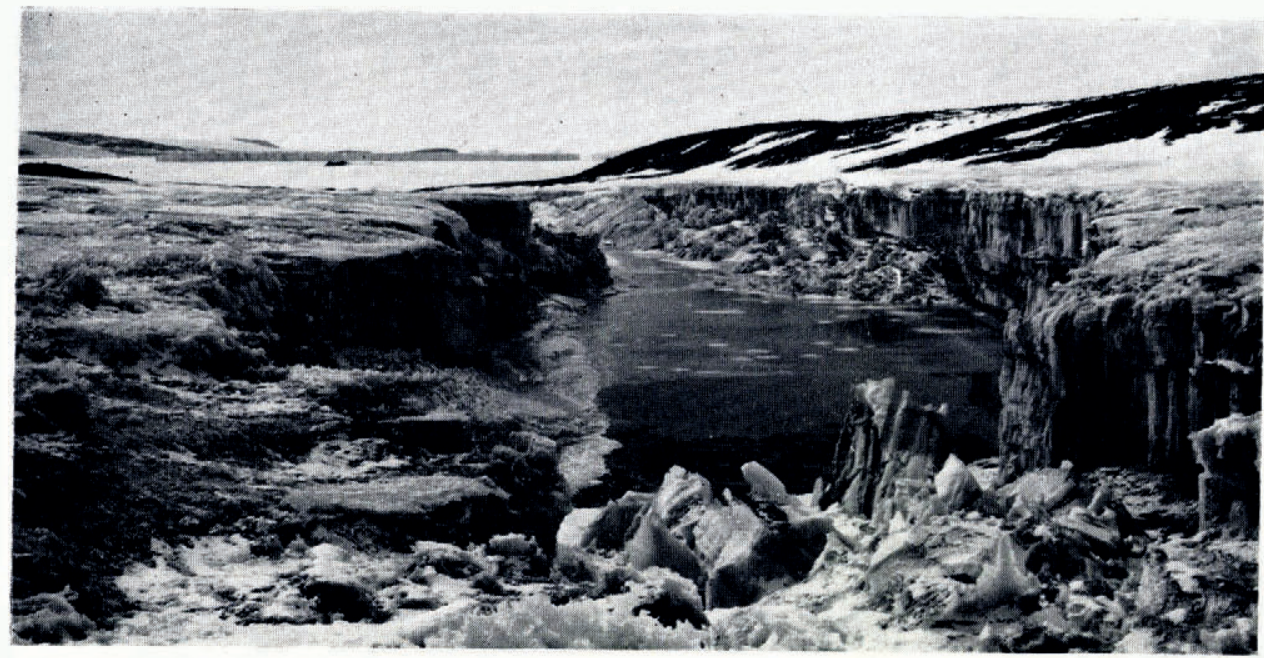

Fig. 6. A canyon cut by the "Scheuren River" in a snowdrift-ice slab. The ice cliffs are in places $7 \mathrm{~m}$. high

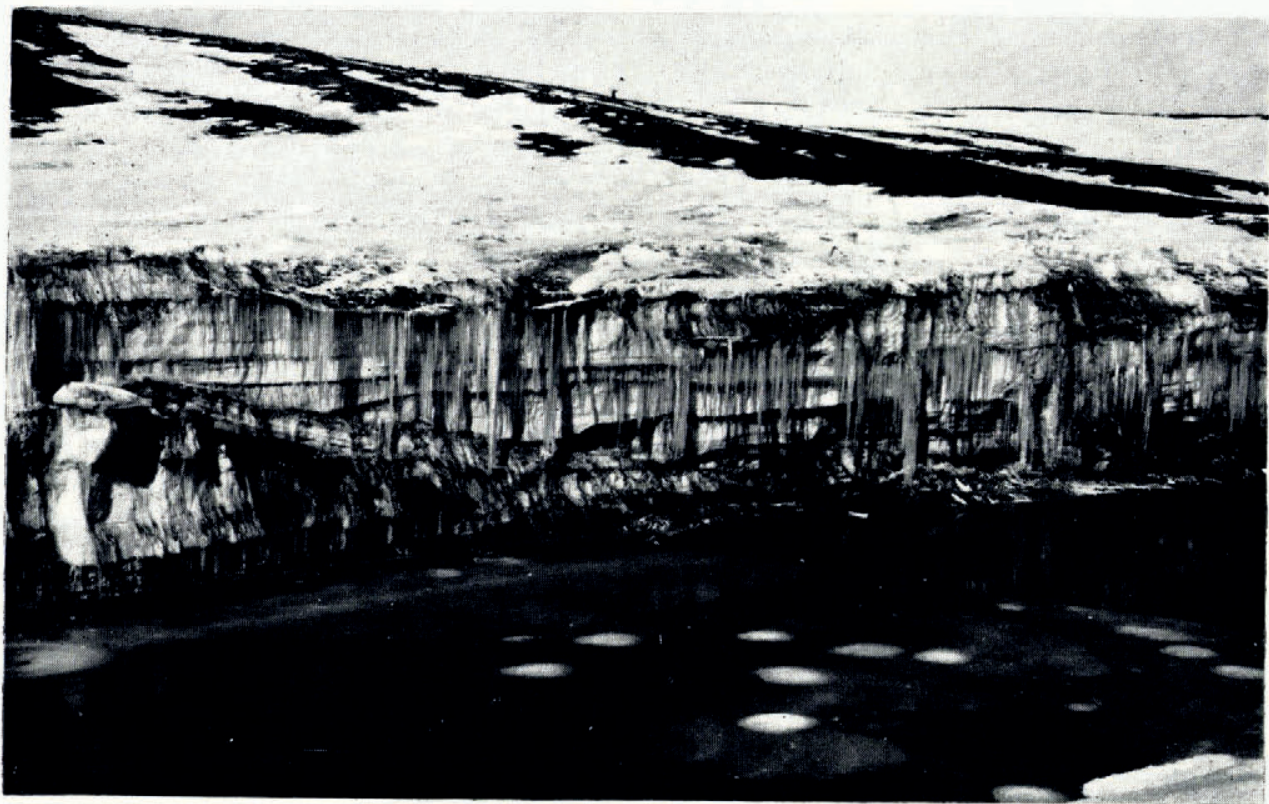
Fig. 7. Several layers of fluviatile sand and gravel interbedded in the snowdrift-ice slab in the "Scheuren valley". The ice cliff is
approximately $7 \mathrm{~m}$. high

An elevated bay-side beach about $19.5 \mathrm{~m}$. above sea-level, high up on the valley wall in the lower part of the "Scheuren valley" (Fig. 5) shows that an arm of the sea extended up the "Scheuren valley" when the ocean was at this level. A series of lower elevated beaches nearby (Fig. 5), in part stream-eroded, may have been bay-mouth beaches. If so, an elongated freshwater lake may have existed for a considerable period of time behind these beaches. The lower part of the "Scheuren valley", following deglaciation, contained first sea ice and later, perhaps, 
lake ice. The presence of the interbedded sand and gravel, and the fact that the existing ice slab slopes seaward, indicate that the part of the ice slab below the marine limit is neither sea ice nor lake ice.

It seems likely that the "Scheuren River"' once ran entirely on the surface of this ice slab and later in a tunnel beneath the ice slab. Collapse of the roof of the tunnel, together with the removal of the collapsed ice by the river, produced the ice-walled canyon in which the river now flows for some of its course. In the formation of the canyon considerable ice was removed. The conspicuous present-day calving of the walls of the canyon (Fig. 6) suggests that it is increasing in size. Late in 1957 the writer saw an ice bridge cut in an ice slab in the valley occupied by the stream which reaches McMurdo Sound just south of Marble Point. The bridge appeared to be a feature of some permanence but had collapsed by the time the writer revisited the area late in $195^{8}$. These facts suggest a recent amelioration of climate.

Negative temperature gradients near the surface of the Antarctic Ice Sheet (Mellor, ig6o, p. 78o-82); historic thinning of the Antarctic Ice Sheet (Shumskiy, I959); retreat of ice shelves and valley and piedmont glaciers (Fuchs, I95I, p. 405, 4I I, figs. 2, 4; Ronne, I948, p. 362 ; Nichols, [1953], p. 39; 196o, p. I431); recent thinning of patches of perennial snow and ice (Hollin and Cameron, I96I, p. 84I ; Yoshikawa and Toya, I957); thicker crusts in the upper layers of snow pits and cores (Giovinetto, I960; Hollin, 1962, p. I8o); and meteorological data (Wexler, 1959, I96r; Mellor, I960) have also been interpreted to indicate a historic amelioration in climate in widely separated areas in Antarctica.

However, Schytt (1953), Mellor (1959, p. 230-32), and Péwé and Church (1962) have made careful studies of the termini of widely separated Antarctic glaciers and have reported neither significant retreat or advance. In this connection it must be remembered that a slight amelioration of climate may take place for a limited period of time in one part of Antarctica while little or no change or even a slight deterioration of climate takes place in another (personal communication from Irving Schell). Perhaps the glaciers studied were so large that their termini were not sensitive to minor historic changes in climate.

\section{$M S$. received 2 June 1964}

\section{REFERENCES}

Fuchs, V. E. 1951. Exploration in British Antarctica. Geographical fournal, Vol. I1 7, Pt. 4, p. 399-42 I.

Giovinetto, M. B. 1 960 . Glaciological studies at the South Pole Station. Union Géodésique et Géophysique Internationale. Monographie No. 5, p. 64 . [Abstract of paper presented at Simposio Antártico Argentino, Buenos Aires, November 1959.]

Hollin, J. T. 1962. On the glacial history of Antarctica. Journal of Glaciology, Vol. 4, No. 32, p. 173-95.

Hollin, J. T., and Cameron, R. L. 196r. I.G.Y. glaciological work at Wilkes Station, Antarctica. Journal of Glaciology, Vol. 3, No. 29, p. 833-43.

Mellor, M. 1959. Variations of the ice margins in East Antarctica. Geographical Fournal, Vol. 125, Pt. 2, p. 230-35.

Mellor, M. 1960. Temperature gradients in the Antarctic Ice Sheet. Fournal of Glaciology, Vol. 3 , No. 28, p. 773-82.

Nichols, R. L. [1953.] Geomorphology of Marguerite Bay, Palmer Peninsula, Antartica. Washington, D.C., Office of Naval Research. (Ronne Antarctic Research Expedition. Technical Report No. 12.)

Nichols, R. L. 1960. Geomorphology of Marguerite Bay area, Palmer Peninsula, Antarctica. Bulletin of the Geological Society of America, Vol. 71, No. 10, p. 1421-50.

Nichols, R. L. 1961. Coastal geomorphology, McMurdo Sound, Antarctica: preliminary report. IGY Glaciological Report Series (New York), No. 4, p. 5 I-IOI.

Nichols, R. L. 1963. Miniature nivation cirques near Marble Point, McMurdo Sound, Antarctica. Fournal of Glaciology, Vol. 4 , No. 34 , p. $477-79$.

Péwé, T. L., and Church, P. E. 1962. Glacier regimen in Antarctica as reflected by glacier-margin fluctuation in historic time with special reference to McMurdo Sound. Union Géodésique et Géophysique Internationale. Association Internationale d'Hydrologie Scientifique. Commission des Neiges et Glaces. Colloque d'Obergurgl, $10-9-18-9$ 1962, p. 295-305.

Ronne, F. 1948. Ronne Antarctic Research Expedition, 1946-1948. Geographical Review, Vol. 38, No. 3, p. 355-91.

Schytt, V. 1953. The Norwegian-British-Swedish Antarctic Expedition, 1949-52. I. Summary of the glaciological work-preliminary report. Fournal of Glaciology, Vol. 2, No. 13, p. $204^{-05}$. 
Shumskiy, P. A. 1959. Sovetskiye glyatsiologicheskiye issledovaniya v Antarktide [Soviet glaciological investigations in Antarctica]. Akademiya Nauk SSSR. Mezhduvedomstvennyy Komitet po Provedeniyu Mezhdunarodnogo Geofizicheskogo Goda. Sbornik Statey. IX i XII Razdely Programmy MGG (Glyatsiologiya $i$ Seysmologiya) [Academy of Sciences of the U.S.S.R. Interdepartmental Committee for Participation in the International Geophysical Year. Collected Papers. Sections IX and XII of the I.G.Y. Programme (Glaciology and Seismology)], No. 2, p. 77-83.

Wexler, H. 1959. A warming trend at Little America, Antarctica. Weather, Vol. I4, No. 6, p. 191-97. Wexler, H. 1961 . Additional comments on the warming trend at Little America, Antarctica. Weather, Vol. 16 ,
No. 2, p. 56-58.

Wright, C. S., and Priestley, R. E. 1922. Glaciology. London, Harrison and Sons, Ltd. (British (Terra Nova) Antarctic Expedition, 1910-1913.)

Yoshikawa, T., and Toya, H. 1957. Report on geomorphological results of the Japanese Antarctic Research Expedition, 1956-57. Antarctic Record, No. 1, p. I-13. [In Japanese, with 3-page English abstract.] 